\title{
Who won the contest for a new property class? Structural transformation of elites in the Visegrád Four region*
}

\author{
Jan Drahokoupil**
}

This paper analyses the transformation of elites in the Visegrád Four countries (namely the Czech Republic, Hungary, Poland and Slovakia). Drawing on a process-tracing analysis, it argues that the emergence of foreign-led economies in the late 1990s was intertwined with political processes in which domestic forces linked to foreign capital were transformed into major elite segments with considerable influence. This elite segment, the comprador service sector, proved to be politically active within the states in Central and Eastern Europe and organized various mechanisms of representation within the state and beyond.

Die Studie untersucht den Wandel der Elite in den Visegrád-Staaten (namentlich die Tschechische Republik, Ungarn, Polen und die Slowakei). Sie zeigt, wie in den späten 1990er Jahren das Entstehen der auslandsgeführten Wirtschaftszweige politisch mit dem Entstehen einer lokalen Elite verflochten war, die sich in den Dienst des ausländischen Kapitals gestellt hat. Diese Elite ein sog. „Comprador Dienstleistungssektor“ - ist zu einer dominanten einflussreichen Teilelite herangewachsen.

Key words: Central and Eastern Europ, class, elites; foreign direct investment

* Manuscript received: 14.03.08, accepted: 25.27 .08 (1 revision)

** Jan Drahokoupil, Research fellow, Mannheim Centre for European Social Research, University of Mannheim. Main research areas: Politics and political economy of Central and Eastern Europe and Central Asia. Corresponding address: jan.drahokoupil@gmail.com. 
In their seminal contribution on capitalist class formation in post-communist Central Europe, Making Capitalism without Capitalists (1998), Eyal, Szelenyi and Townsley concluded that it was too early to say who had won the contest for a new propertied class. The outcome of the process of class formation was unclear, and there were three major candidates to form the new propertied class: the technocratic-managerial elite, foreign investors with their 'comprador intellectual allies', and the new entrepreneurs who had started their own small businesses and hoped to expand (Eyal et al. 1998:5). Ten years later, we are in a position to identify the winner. I will argue that it was 'foreign investors with their comprador intellectual allies' who gained the upper hand in Central and Eastern Europe. More specifically, I claim that the domestic comprador forces rather than their foreign allies had (and still have) a major role in domestic politics. The rise of these forces was intertwined with the emergence of foreignled economies and consolidation of the competition state.

Below, I first introduce my approach to the study of elites and relate it to major perspectives in this field. The class perspective I employ emphasizes the ways in which the political and economic structures condition the composition and strategic preferences of the elites as well as the power relations among them. Then, I deal with the political-economic developments in the region that structured incentives, opportunities and constraints for individual elite segments, which in turn shaped the political-economic evolution. In particular, I describe political-economic convergence towards foreign-led economies and a specific model of the competition state in the Visegrád Four (V4) region. As I argue in the third section, political-economic convergence was accompanied by an emergence of similar elite structures. Thus, focusing on the V4, I compare the most similar cases in Central and Eastern Europe (CEE). The fourth section specifies my understanding of the comprador elite segments that gained ascendancy in domestic politics. Then, I expand on the variety of their composition in individual countries. Finally, I analyse the political role of foreign investors.

\section{Research on elites, class analysis and the strategic-relational approach}

There are two major paradigms informing research on the 'ruling class' in Central and Eastern Europe. First, the elitist approaches focuses on the occupants of elite positions, their social, cultural, ideological and economic 
attributes, and career histories ${ }^{1}$ The personal composition of elites is assumed to have important implications for their strategies and for the shape of the politicaleconomic environment in general. Thus, within this tradition, variables such as a degree of elite replacement are important factors explaining differences in political-economic outcomes (King 2007). The elitist paradigm comprises much of the actually existing empirical research on elites (Mansfeldová/Stašková 2007), the stratification research (Machonin et al. 2006) and the actor-centred scholarship, such as the epistemic communities approaches (Fisher et al. 2007).

Second, class analyses, including those in the Marxist, Weberian and Durkheimian traditions, are less concerned with the occupants of the elite positions, focusing rather on the way these positions are constituted by the social relations that determine people's access to economic resources (Wright 2005). The class paradigm thus embeds elite positions in society: it investigates the way political and economic relations structure the incentives, opportunities, constraints and power of those occupying individual elite positions. Research in this tradition includes the 'neoclassical sociology' approach to transition (Eyal et al. 1998), neo-Gramscian contributions (Shields 2004) and a social class approach (Lane 2005a).

A distinction can be made between two principal research questions and agendas addressed from both the elitist and class perspectives. First, there are questions of life chances and elite/class recruitment. What explains the inequalities in life chances and distribution of various social assets? Who occupies elite positions, such as the management of 'top companies' and executive positions within the state? What are the patterns of recruitment into ruling classes? Second, there are questions of elite/class structure and the social function of individual elites or class factions. What is the role of elite positions within the wider social structure? What are their structural incentives, constraints and opportunities? More specifically, what are the important features of individual 'top companies'? What is the nature of ties and divisions within elites? While much of the existing research on Central and Eastern Europe has very much focused on the first set of questions, this article approaches the transformation of elites in the region from the perspective of the second set. Such a relational approach to the ruling class, its individual factions and their wider political role allows us to investigate their wider social role and constitution.

1 A group of rulers relatively closed off from those who are ruled (Evans, M. 2006), elites are usually defined as office incumbents in the political sphere and as holders of command positions in 'top companies' in the economic sphere. A more broad definition would include those at the top of various stratification fields that guide the distribution of various social assets or capitals. Members of the group are selected the virtue of a set of resources, including economic, political, ideological or technical assets. 
Theoretically, this paper draws on the perspective of strategic-relational state theory (Drahokoupil et al. 2008). Accordingly, the social relations of production, institutions and ideas have a major role in constituting social forces and in mediating their relative power and social influence. These structural features produce a field of force exerting pressures and setting limits on what is achievable. In the other words, they constitute a (strategically selective) environment that provides advantages to some actors and certain strategies over others. Yet, actual outcomes are produced by strategic actors in social struggles. Only in transnationally constituted domestic politics are some structural opportunities enacted - or some social mechanisms activated - while other are suppressed or muted. Analytically, the strategic-relational perspective has a number of implications for analysis at the level of elites. First, it implies a classanalytic perspective. Thus, this paper investigates how 'the social relations of production' (as in Marx) or 'market capacity in exchange relations' (as in Weber) shape the formation, interests and social power of elites. Therefore, in order to understand limits, opportunities and incentives for individual social actors and social sources of power, this analysis starts with a political-economic account of the transformations in Central and Eastern Europe.

Second, class formation is not a matter of automatism, but a historically contingent outcome of political processes and struggles. A relational understanding of elites therefore requires a historical political analysis. Thus, the primary source of data in this paper is not elite or stratification survey, but a process-tracing analysis, which also draws on non-probability elite interviews (Tansey 2007). Such analysis allows us to identify a degree (or a lack) of cohesion on the part of individual elite/class segments as well as their actual (rather than declared) political preferences and strategies. Finally, contrary to a popular assumption common to the actually existing empirical research on elites, business and political elites can be understood neither as independent/autonomous nor as homogenous. The 'radical autonomy assumption' finds some theoretical support in the state-centric stream of historical institutionalism (Evans et al. 1985). Yet, such a perspective is not tenable in the light of a large body of research, including the one I present below (Jessop 1990:281-283). I use the process-tracing analysis to identify the (power) relations among individual elite segments, including links among political and business elites. The latter includes not only personal links and career patterns, but also congruence of individual interests and the structural dependence of 'political elites' on investment in productive activities controlled by the 'economic elites' (Block 1987; Jessop 1990). Moreover, individual elite segments can be integrated into a power bloc - a dynamic coalition of social 
forces which can be forged through a hegemonic project articulating a 'general interest'.2

\section{The emergence of foreign-led economies and the rise of the competition state}

The economic recovery of the late nineties was accompanied, and largely driven, by an upsurge of foreign direct investment (FDI). The economies in the region underwent a process of rapid and thorough internationalization, with export activities increasingly focused on the EU market. It is a commonplace to observe that foreign-led economies have crystallized in CEE, with foreign control of leading export industries and most public utilities, and with unprecedented levels of foreign dominance in the banking sector. The Czech Republic, Hungary and Slovakia have become as internationalized as the most open economies of the small European states such as Sweden, the Netherlands and Denmark. Poland has overtaken the other big European economies, Germany and France, albeit by a narrow margin (UNCTAD 2007). The region, however, has been internationalized in a dependent way (Vliegenthart/Overbeek 2007) or through 'passive extroversion' (Becker 2007). While the inward FDI stock is soaring, there is very little outward FDI from CEE. An interplay of inherited structural and institutional advantages with domestic political choices has generated distinct clusters of capitalist variety: the V4 region with foreign-led economies with a high share of complex activities, a more autonomous Slovenian capitalism with a high share of complex activities, and foreign-led economies dominated by semi-manufacturing and light-industry in SouthEastern Europe (Bohle/Greskovits 2007; Becker/Weissenbacher 2007; Drahokoupil 2008a).

The emergence of the foreign-led economies has been accompanied by the rise of the competition states. The underlying aim of state intervention is to manage the insertion of local/national economy into the flows of 'global' capitalism. After a period of distinct national strategies in the early nineties, some of which were relatively hostile to FDI, both economic and social polices are (to different extents) now subordinated to the competitiveness agenda. There are a variety of competition states, coupled with the capitalist variety in the region. In the V4, the states have converged to form a distinctive model of the competition state that aims at upgrading industrial bases by attracting foreign investment through

2 The notion of a hegemonic project brings together the structural constraints and opportunities, on the one hand, and the strategic agency and conjunctural political struggles, on the other. It denotes a temporary synthesis between the perspective generated by an ascendant trend in the economy and the capacity of a set of social forces operating in the context of the state (or a number of states) to translate this perspective into a general (comprehensive) programme for society as a whole (Jessop 1990; Jessop 2007). 
targeted subsidies, discriminating among investors in terms of their potential contribution to the local economy. This strategy, which I call Porterian (Drahokoupil 2007a, 2007b), is distinct not only from a 'Schumpeterian' (Jessop 2002) or 'flexible developmentalist' (Ó Riain 2000) strategy known from the West, but also from the low-cost or stability-driven strategies in the rest of CEE. In Porterian logic, competitiveness is achieved from high and rising levels of labour productivity associated with high-tech production processes and highly skilled labour-intensive activities (Porter 1990). The main means of Porterian intervention in the V4 are different investment subsidies, including tax breaks, employee-training grants and subsidies for infrastructure development. After introducing an investor to the locality, the states attempt to embed it in the local economy and thus create potential for spillover effects and industrial upgrading, and reduce the risk of its departure by making it more locality dependent and thus less mobile.

\section{Competition state as a hegemonic project: the time of comprador elites}

The competition state became predominant all over the V4 by 1999 . Governments pursued it regardless of ruling party coalitions (Bohle 2006). The political support of the competition state goes beyond narrow short-term interests and immediate material concessions; it transcends party divisions and party politics, even though it can occasionally become politicized and connected with the party in power, giving rise to a false impression that the competition state is a project of the ruling party rather than a broader hegemonic project. The competition state has a solid political, institutional and structural underpinning within the V4 (Drahokoupil 2008b). The structural dependence on foreign investors, territorial non-correspondence between the scales of political regulation and capital accumulation, the European regulatory framework, the scalar organization of governance and some of the interpretative frameworks that prevail among policy makers are the main structural features that provide the project of the competition state and social forces promoting it important strategic advantages. Implementation of the competition-state project cannot just be understood as an outcome of unequal distribution of power between foreign investors and the governments, as the state-centric understanding of statemultinational bargaining would have it (Vernon 1998; Eden et al. 2005; Meyer/Jensen 2005). The governments are not social actors independent of other social forces, including the investors. Rather, the actual policy outcomes are products of the agency of particular social forces mediated through structures of representation. It is the privileged position of social forces connected to FDI within particular states and societies that explains the support for the competition agenda. 
The emergence of the competition state brought the comprador segments of domestic elites to the fore in the respective states. At the same time, this was also conditional upon their unfolding hegemonic role and shaped by their political activities. The political position and agency of the comprador service sector do not explain policy transformation per se. They worked as a linking factor that influenced when, how and in what form such a shift towards the competition state took place. The international political-economic environment and the neoliberal transition strategies created a field of force that allowed this sector to grow in influence as its interests become increasingly 'universal' (Drahokoupil 2008b).

\section{What is the comprador service sector?}

The literature on (FDI) dependent development has emphasized the crucial role of domestic actors in the political coalitions underpinning the externally oriented projects. Poulantzas used the term comprador bourgeoisie to describe class relation at the periphery. The comprador bourgeoisie was defined as 'that faction whose interests are entirely subordinated to those of foreign capital, and which functions as a kind of staging-post and direct intermediary for the implantation and reproduction of foreign capital' (Baran 1957; Poulantzas 1976:42). As far as CEE is concerned, Holman has argued that the new power elites in the region cannot be characterized as propertied comprador bourgeoisie, but rather as managerial and administrative elites that have the same function as that of the comprador bourgeoisie (Holman 2004:223). Lane proposed that a transnational political class, an alliance between internal elites and an external global political class in particular, was a crucial agent of change in CEE in the nineties, which effectively precluded development of social democratic or corporatist forms of national capitalism (Lane 2005a; Lane2006). From an elite perspective, Machonin, Tuček and Nekola, observed that the influence of domestic elites is limited by an 'apparent hegemony of foreign capital'. They argued that the influence of local managers working for foreign affiliates is not based on wealth, but their 'mandates from abroad' (Machonin et al. 2006). However, the comprador segments are not specified empirically in these accounts. Holman and Lane offer an analytical (rather than empirical) understanding; yet they do not identify differences among domestic elites in their approach to FDI and fail to distinguish important differences between the limited importance of FDI in the early nineties and its hegemonic role later in the decade (Drahokoupil 2008c).

I characterize the domestic actors linked to FDI as the comprador service sector. The comprador service sector comprises various groups providing service for foreign investors. It includes local branches of global consulting and legal advisory firms and their local competitors, companies providing other services to foreign investors, and officials from FDI-related state bodies. This group is 
comprador as it is structurally dependent on transnational capital, whose interests it represents. Structurally, this sector is not a bourgeoisie, as it constitutes neither a propertied class nor a professional managerial class, whose interests are linked to that of company owners ${ }^{3}$ As far as the economic sphere is concerned, therefore, the nature of its links to foreign capital can be characterized mainly by the Weberian notions of 'market capacity' and 'income class': that is, by its ability to take the opportunity to utilize services to foreign investors at above-average compensation. Yet, recent trends, most notably the emergence of regional developers such as the IPEC Group, ${ }^{4}$ point to processes of embourgeoisement within this sector, giving rise to Eastern European developers with significant local ownership as well as managerial cadres structurally linked to owners. The sector thus increasingly represents a 'social class' linked to foreign capital through its position within the social relations of production.

The comprador service sector is a nodal point and organizer of the transnational power bloc centred on multinational investors. The strategies pursued by the comprador service sector have often facilitated the learning process in which the policy makers realize the imperatives of the structural power of multinationals and reorient the internally oriented polices towards the externally oriented framework. More generally, the comprador service sector helps to translate the structural power of transnational capital into tactical forms of power within the states that enable agential power to work in sync with the interests of the multinationals. The structural power of capital is derived from the dependency of the state and society at large on the investment decisions that are controlled by capital (e.g. the possibility of an investment strike and state revenue dependence). ${ }^{5}$ The power through agency is exercised by direct participation of business within and in relation to the state institutions. The notion of tactical power introduces an intermediate level between the structural and agential faces of power. Tactical power refers to the ability to control settings of interaction or the respective field of force (Wolf 1990). It enables structural power to work in sync with its agential counterpart. ${ }^{6}$

3 I use the term 'sector' rather than 'group' or 'elite segment' to define this group with reference to their links with relations of production and/or exchange rather than to their personal composition.

4 See www.ipec-group.com.

5 See, inter alia, Hirschman (1970); Przeworski/Wallerstein (1988); Offe/Ronge (1975); Gough (1979). For a detailed discussion of the structural/agential power of capital, see Gill/Law (1989) and Farnsworth (2004).

6 Wolf's notion of tactical power largely corresponds to the agenda-setting face of power as conceptualized by the faces of power debate in political science (Hay 2002:174-178). 
Influence of the comprador service sector varies. Its power is largely a function of the degree of internationalization of a given economy and thus of the importance of foreign investors. Internationalization in CEE was accompanied, as well as shaped by, the consolidation of the comprador service sector and its structures of representation. In the Czech Republic, the comprador service sector had an important political role in shaping, organizing and setting the agenda of the U-turn in the approach of the government towards FDI in the mid-nineties; its members assumed important positions within the government; and it organized important networking and lobbying forums linking politicians, state officials, and foreign investors (Drahokoupil 2008b:5). Networking and lobbying forums of the Hungarian comprador service sector are widely understood to be very effective. Its preferences, communicated through these channels, have been reflected in changes to labour market policy, tax legislation and the structure of investment incentives ${ }^{7}$ In Slovakia, the comprador service sector was involved in the consultation over legislation enacting the neoliberal offensive of the early 2000s. In particular, it significantly influenced radical reform of the labour law (AmCham Slovakia 2002; Bohle/Husz 2005; Bohle/Greskovits 2006). In Poland, lobbying tends to take place through individual channels and particularistic networks rather than through collaborative efforts (Domański 2005). Institutionalized networking and lobbying forums are therefore considered less important (Jasiecki 2002). At the same time, strong FDI-growth coalitions often consolidate in the regions. ${ }^{8} \mathrm{I}$ expand on the different compositions of the comprador service sector as well as on the respective structures of representation in the next section.

\section{Varieties of the comprador service sector and its structures of representation}

The comprador service sector constitutes the major element and organizer of the power blocs underpinning the competition state in the V4 region It is particularly integrated in the Czech Republic and Hungary. In Poland, it is more fragmented and organized on a regional basis. In the Czech Republic, the state

7 Interviews with Péter Ákos Bod, Minister for Industry and Commerce in 1990-1991, governor of the National Bank of Hungary in 1991-1994, Budapest, 15 November 2007; Magdolna Sass, senior research fellow at the Institute for Economics of the Hungarian Academy of Sciences, Budapest, 15 November 2007; György Csáki, Budapest, 15 November 2007; and Takács, Katalin Zsámboki and János Rajki of the Hungarian Trade and Development Agency (ITDH), Budapest, 16 November 2007. (AmCham Hungary 2006; AmCham Hungary 2007).

8 Interview with Bolesław Domański and Krzysztof Gwosdz, Kraków, 6 November 2007; Wojciech Jarczewski, Instytut Rozwoju Miast [Institute of Urban Development in Kraków], 8 November 2007, Kraków. See also Banaszek (1999:61-71). 
faction of the power bloc, the investment promotion agency CzechInvest in particular, has had a major role in organizing the comprador service sector. This is somewhat exceptional. The importance and consolidation of the state faction in the Czech Republic can be explained by the necessity of concerted action in order to facilitate delivery of service to he investors within the state and to push for a more favourable policy to FDI in the environment, which was particularly hostile to such efforts in the political sphere though ripe with FDI opportunities in the sphere of accumulation.

State and corporate factions of the comprador service sector are linked by the common interest of promoting FDI; they are integrated through personal ties, institutional channels, material benefits and recruiting patterns. First, the two factions are integrated through flows of people between them. The main protagonists have tended to switch from working for governments to jobs in consulting agencies, developers or law offices, and often back. Second, the state and public factions have developed a number of institutional channels and forums of cooperation. For instance, such linkages have been established through the co-opting of private-sector representatives in supervisory-boards of investment promotion agencies (McMenamin/Hill 2004). In the Czech Republic, the comprador service sector has created a special networking and lobbying body, the Association for Foreign Investment. Elsewhere, foreign chambers of commerce play important roles. Third, flows of material benefits between state and private factions of the comprador services sector are also important mechanisms of integration. The externally oriented project provides aboveaverage contracts for the comprador service sector and great potential of material benefits in the form of various commissions and fees for its state faction. Finally, the two factions of the comprador service sector are integrated through recruitment patterns. A position in the state faction, followed by employment with the comprador service sector or direct employment with multinationals, often works as two logical steps on the career ladder, especially for graduates (Drahokoupil 2008b).

The Czech case aside, investment promotion agencies and state factions of the comprador service sector tend to be less active and consolidated than the corporate segment. In stark contrast to the Czech case, the Slovak investment promotion agency has lacked political agency and had virtually no impact on changing the approach to FDI (FIAS 2005: pp. A-8, A-9, cited in Trník 2007:27). ${ }^{9}$ The difference with the Czech case can be explained by the much smaller opportunities for FDI lost to a prospective comprador sector in the early and mid-1990s. However, not much changed later. This was largely because

9 See Peter Barecz, 'SARIO agency playing catch-up to region,' The Slovak Spectator 6 (35)/2000; Keith Miller, 'SARIO promising to bring vital FDI,' The Slovak Spectator 6 (28)/2000; Trník (2007). 
other bodies of the state apparatus, most notably the Ministry of Economy and the Governmental Assignee for Development of Automotive Industry (which functioned in the period 1997-2003), ${ }^{10}$ established themselves as centres of representation of the comprador service sector within the state and benefited from the surge of FDI in the late nineties (Trník 2007; Zamkovský 1999). Working in 'a truly welcoming land for foreign investors', ${ }^{11}$ the Hungarian investment promotion agency has enjoyed only a minor political role. It only started to develop events and networking activities such as those of CzechInvest in 20087. ${ }^{12}$ Similarly, the Polish Information and Foreign Investment Agency does not play such an important role in organizing the comprador service sector. While it organizes conferences and discussions, its networking role is limited. ${ }^{13}$ Importantly, however, it works as a mechanism translating the structural pressure of incentive competition in the region into the agenda of Polish government. Its publications and reports to the government tend to analyse cases where Polish regions have been outbid by their competitors, identify disadvantages of the Polish incentive scheme in comparison to regional competitors, and propose more competitive measures. ${ }^{14}$

Where the state faction is less consolidated and active, business associations play major roles. In Hungary, the American Chamber of Commerce in Hungary (AmCham Hungary) constitutes the core of the comprador service sector along with organizations like the Hungarian European Business Council (HEBC), ${ }^{15}$ the Joint Venture Association (JVA), ${ }^{16}$ the British Chamber of

10 The function of governmental assignee was created by the Slovak government's resolution \#447/1997, dated 17 June 1997, and resolution \#750/2000, dated 20 September 2000.

11 Csaba Kilián (investment director of ITDH), 'Background information for the Max Planck-ITDH meeting', Budapest, 16 November 2007.

12 Interview with Tibor Takács, Katalin Zsámboki and János Rajki of ITDH, Budapest, 16 November 2007.

13 Interview with Wojciech Szelagowski, vice-president of PAIiIZ, Munich, 25 October 2007.

14 Interview with Wojciech Szelagowski, 25 October 2007. See PAIiIZ (2004:21-22, 65).

15 The Hungarian European Business Council was established in 1998 upon the initiative of the ERT. HEBC is the Business Council of the Chairmen and CEOs of Hungarian affiliates of ERT enterprises and significant investors in the Hungarian economy such as ABB, Akzo Nobel, BAT, BT, Electrabel, Electrolux, Ericsson, MOL, Nestlé, OMV, Philips, SAP, Suez Environnement and Unilever.

16 Already established in 1986, the JVA aims to 'represent, protect and exert by all legal means the specific interests of partly or wholly foreign-owned companies registered in Hungary' (JVA mission statement, available at http://www.jointventure.hu/ index.php?cat=intro\&lang=en). Its 400-member base includes ABB, Alstrom, Flextronics, Nokia Hungary, Deloitte, and PricewaterhouseCoopers. 
Commerce in Hungary, and the German-Hungarian Chamber of Industry and Commerce. Established in November 1989 by 32 American companies, AmCham Hungary has been particularly active as far as both lobbying and networking activities are concerned. ${ }^{17}$ AmCham Hungary has been transformed from a representative of US business into a major hub of networking and lobbying activities of large transnational companies active in Hungary including the domestic multinationals, such as Hungarian oil giant MOL. As foreign investors had previously had a record of involvement in the country and since Hungary was the first country to open up to foreign investors in the privatization process, foreign investment banks and consulting agencies, such as PricewaterhouseCoopers, established a strong presence in the country at the beginning of the nineties. They advised both the government and investors on privatization and were often instrumental in introducing investors to the respective ministers and bureaucrats. ${ }^{18}$ They also quickly established formal networking forums and channels of influence. It is important to note in this context that, despite important differences in the manner and timing of its consolidation, the social composition of the comprador elite personnel is similar to its Czech counterpart: global consulting agencies, investment banks and the affiliates of other investors would hire Hungarians with local histories, even to very senior positions.

In Poland, the development of extensive relations with various domestic actors and the hiring of Polish managers were also vital components in foreign investors' strategy of 'learning the ropes in a generally unknown business and social environment' (Domański 2005:157). As elsewhere, global consulting agencies were very active in advising on privatization processes, developing real-estate infrastructure for foreign businesses and establishing links with relevant parts of the state apparatus (Shields 2003:236). Foreign business organizations, most notably the British Polish Chamber of Commerce and AmCham Poland, have also been very active over time in organizing networking and lobbying activities. Their events are frequently attended by senior servants and politicians. Established in the 1990 through an initiative of the US Embassy in Warsaw, Amcham Poland developed various lobbying activities to support more open policies to FDI and a favourable business climate in Poland. It also promoted positive attitudes towards FDI in Poland. For instance, in 1999, when a series of articles condemned foreign investment as responsible for Poland's large trade deficit, AmCham responded by a campaign emphasizing the benefits

17 See annual reports of AmCham Hungary. The 2000-2007 volumes are available athttp://www.amcham.hu/annualreport/.

18 Interview with György Csáki, economic advisor to the government in 1994-1998, and member of the Board of Directors of the State Privatization Holding in 1996-1998, Budapest, 15 November 2007. 
of foreign investment. ${ }^{19}$ However, as mentioned above, foreign business chambers, as well as other business organizations, are not considered to be very influential in Poland (Jasiecki 2002). Business groups, including the multinationals, are not particularly integrated.

Finally, AmCham is the most active business association in Slovakia as well. It is made up of the usual mix of Slovak managers hired by multinationals and of people working for global consulting companies. Its events host politicians and senior civil servants from across the political spectrum.

\section{The multinationals}

The transnational corporations investing in the CEE region represent the main productive element or material base of the externally oriented power bloc. In a classic understanding, mobile asset holders like multinationals would prefer to exert influence by using their structural power (exit strategy of silent withdrawal), while the less mobile factions would have greater incentive to invest in influence through agency (voice) (Hirschman 1970). The empirical record does indeed show that mobility or the scale on which the respective actors operate influences the strategies that they employ. However, the strategies of multinationals show that exit and voice are by no means exclusive. On the contrary, the multinationals have been employing not only exit strategies including playing off the states against each other when making their investment-location decision — but also agency through voice. While the comprador service sector has played the major role in representing transnational capital within the states, the multinationals have not left political agency to this sector only.

The multinationals become more concerned with the local policy environment and thus become more politically active, the more committed they become in their local operations. In the early nineties, foreign investors preferred to engage in low-commitment strategies, such as involvement through trade and subcontracting, rather than investing in the V4 directly (Martin 1998/1999). The quality of local regulatory environments and the stability of institutional frameworks are major concerns for investors engaging in such low-commitment activities that were predominant in the early nineties. The association agreements with the EU initially provided sufficient guarantee in this respect. Since the mid-1990s, however, the investors have shifted into highercommitment and less mobile activities. Comparative quantitative evidence based on a large company-level survey showed that TNCs - those operating in East Europe and Central Asia in particular - enjoy a better business climate than the

19 Tony Housh, AmCham Executive Director, American Investor, June 1999, cited in 'AmCham's 15 year history', http://amcham.pl/index.php?mod=page\&page=1_history. 
domestic firms because of their bargaining power in negotiating entry conditions and their subsequent political activism in the host country (Desbordes/Vauday 2007). After the state strategies reoriented, the multinationals did not leave the political agency to the comprador service sector only. On the contrary, they proved to be quite active in promoting their interests through direct agency. Apart from supporting and taking part in the activities organized by the comprador service sector, foreign investors sometimes engage in independent lobbying activities. Direct lobbying through particularistic networks is especially important in Poland. Agency-based activities of the multinationals are very efficient in addressing investors' concerns and promoting favourable policies throughout the V4 (Bohle/Husz 2005). In Poland, for instance, the TNCs were 'an active force' lobbying for the country's integration into the EU (Domański 2003:105).

\section{Conclusion}

The emergence of foreign-led economies and the rise of the competition state gave domestic elites linked to foreign capital considerable influence. This segment of elites, the comprador service sector, proved to be politically active within the states in Central and Eastern Europe and organized various mechanisms of representation within the state and beyond. A probabilistic elite survey would not necessarily reveal any special personal traits of this segment of elites. Indeed, there was almost certainly a significant recruitment from elites which were previously associated with more domestically oriented segments of the economy. Therefore, in order to understand the preferences and strategy of a particular elite segment, an essentialist elite perspective deriving strategic orientation from personal composition may be misleading. Instead, I proposed to understand elite preferences by embedding them in social relations of production and linking their preferences and strategy to the incentives of the environment.

\section{References}

AmCham Hungary. (2006): Annual report 2006. Budapest: Ammerican Chamber of Commerce in Hungary.

AmCham Hungary. (2007): Annual report 2007. Budapest: Ammerican Chamber of Commerce in Hungary.

AmCham Slovakia. (2002): Report on the activities of the labor law task force of AmCham Slovakia. Bratislava: AmCham Slovakia.

Banaszek, D./Dziemianowicz, W./Papliñski, A./Seges, R./Szemplinska, M./Wolff, J. (1999): Inwestycje zagraniczne $\mathrm{w}$ gminie (Foreign investment in a region). Warsaw: Skigraf on behalf of PAIZ.

Baran, P. (1957): The political economy of growth. New York: Monthly Review Press. 
Becker, J. (2007): Akkumulation, Regulation, Territorium: Zur kritischen Rekonstruktion der französischen Regulationstheorie (2nd ed.). Marburg: Metropolis.

Becker, J./Weissenbacher, R. (Eds.). (2007): Dollarization, Euroization and financial instability: Central and Eastern European countries between stagnation and financial crisis? Marburg Metropolis-Verlag.

Block, F. (1987): Revising state theory: Essays in politics and postindustrialism. Philadelphia: Temple University Press.

Bohle, D. (2006): Neoliberal hegemony, transnational capital and the terms of EU's eastwards expansion, in: Capital and Class, 88, 57-86.

Bohle, D./Greskovits, B. (2006): Capitalism without compromise: Strong business and weak labor in Eastern Europe's new transnational industries, in: Studies in Comparative International Development, 41, 1, 3-25.

Bohle, D./Greskovits, B. (2007): Neoliberalism, embedded neoliberalism, and neocorporatism: Paths towards transnational capitalism in Central-Eastern Europe, in: West European Politics, 30, 3, 443-466.

Bohle, D./Husz, D. (2005): Whose Europe is it? Interest group action in accession negotiations: The cases of competition policy and labor migration, in: Politique Europeenne, 15, 85-112.

Desbordes, R./Vauday, J. (2007): The political influence of foreign firms in developing countries, in: Economics and Politics, 19, 3, 421-451.

Domański, B. (2003): Industrial change and foreign direct investment in the postsocialist economy: The case of Poland, in: European Urban and Regional Studies, 10, 2, 99118.

Domański, B. (2005): Transnational corporations and the postsocialist economy: Learning the ropes and forging new relationships in contemporary Poland. in: Alvstam, C.G./Schamp, E.W. (eds.): Linking industries across the world: Processes of global networking, Adershot: Ashgate, 147-172.

Drahokoupil, J. (2007a): Analyzing the capitalist state in post-socialism: Towards the Porterian workfare postnational regime, in: International Journal of Urban and Regional Research, 31, 2, 401-424.

Drahokoupil, J. (2007b): The state of the capitalist state in east-central Europe: Towards the Porterian workfare post-national regime? in: Sergi,B.S./Bagatelas, W.T./Kubicová, J. (eds.): Industries and markets in Central and Eastern Europe, Aldershot, UK: Ashgate, 175-196.

Drahokoupil, J. (2008a): After transition: Varieties of political-economic development in Eastern Europe and the former Soviet Union, in: Comparative European Politics, 6, 3.

Drahokoupil, J. (2008b): Globalization and the state in Central and Eastern Europe: The politics of foreign direct investment. London: Routledge.

Drahokoupil, J. (2008c): The rise of the competition state in the Visegrád Four: Internationalization of the state as a local project. in: Van Apeldoorn, B./Drahokoupil, J/Horn, L. (eds.), From Lisbon to Lisbon: The contradictions and limits of neoliberal European governance. Basingstoke: Palgrave, forthcoming. 
Drahokoupil, J./Van Apeldoorn, B./Horn, L. (2008): Introduction. in: Van Apeldoorn, B/Drahokoupil; J./Horn, L.(eds.): Contradictions and Limits of Neoliberal European Governance: From Lisbon to Lisbon. Basingstoke: Palgrave.

Eden, L./Lemway, S./Schuler, D.A. (2005): From the obsolescing bargain to the political bargaining model, in: Grosse, R. (ed.), International business and government relations in the 21st century, Cambridge: Cambridge University Press, 251-272.

Evans, M. (2006): Elitism. in: Hay, C/Lister, M./Marsh, D.(eds.): The state: Theories and issues, Basingstoke: Palgrave Macmillan,

Evans, P./Rueschemeyer, D./Skocpol, T. (Eds.). (1985): Bringing the state back in. Cambridge and New York: Cambridge University Press.

Eyal, G./Szelenyi, I./Townsley, E.R. (1998): Making capitalism without capitalists: Class formation and elite struggles in post-communist Central Europe. London and New York: Verso.

Farnsworth, K. (2004): Corporate power and social policy in a global economy: British welfare under the influence. Bristol: The Policy Press.

Fisher, S./Gould, J./Haughton, T. (2007): Slovakia's neoliberal turn, in: Europe-Asia Studies, $59,6,977-998$.

Gill, S./Law, D. (1989): Global hegemony and the structural power of capital, in: International Studies Quarterly, 33, 4, 475-499.

Gough, I. (1979): The political economy of the welfare state. London: Macmillan.

Hay, C. (2002): Political analysis. Basingstoke and New York: Palgrave.

Hirschman, A.O. (1970): Exit, voice and loyalty: Responses to decline in firms, organizations and states. Cambridge, MA: Harvard University Press.

Holman, O. (2004): Integrating peripheral Europe: The different roads to 'security and stability' in Southern and Central Europe, in: Journal of International Relations and Development, 7, 2, 208-236.

Jasiecki, K. (2002): Elita biznesu w Polsce: Drugie narodziny kapitalizmu (Polish business elite: Capitalism's second birth). Warsaw: IFiS PAN.

Jessop, B. (1990): State theory: Putting the capitalist state in its place. University Park, PA: Pennsylvania State University Press.

Jessop, B. (2002): The future of the capitalist state. Cambridge, UK and Malden, MA: Polity Press.

Jessop, B. (2007): State power: A strategic relational approach. Cambridge: Polity Press.

King, L.P. (2007): Central European capitalism in comparative perspective. in: Hancké, B/Rhodes, M./Thatcher, M. (eds.), Beyond varieties of capitalism: Conflict, contradictions, and complementarities in the European economy, Oxford: Oxford University Press, 307-327.

Lane, D. (2005a): Revolution, class and globalization in the transition from state socialism, in: European Societies, 7, 1, 131-155.

Lane, D. (2005b): Social class as a factor in the transformation of state socialism, in: Journal of Communist Studies and Transition Politics, 21, 4, 417-435. 
Lane, D. (2006): From state socialism to capitalism: The role of class and the world system, in: Communist and Post-Communist Studies, 39, 135-152.

Machonin, P./Tuček, M./Nekola, M. (2006): The Czech economic elite after fifteen years of post-socialist transformation, in: Czech Sociological Review, 42, 3, 537-556.

Mansfeldová, Z./Stašková, B. (2007). Výzkum politických a ekonomických elit v České republice (Political and economic elites in the Czech Republic). Prague: Sociologický ústav AV ČR.

Martin, R. (1998): Central and Eastern Europe and the international economy: The limits to globalisation, in: Europe-Asia Studies, 50, 1, 7-26.

Martin, R. (1999): Transforming management in Central and Eastern Europe. Oxford: Oxford University Press.

McMenamin, P./Hill, S. (2004): Survey of performance of investment promotion agencies. in: Promoting foreign direct investment in Central and Eastern Europe and the CIS, Geneva: United Nations Publications, 25-38.

Meyer, K.E./Jensen, C. (2005): Foreign direct investment and government policy in Central and Eastern Europe. in: Grosse, R. (ed.): International business and government relations in the 21st century, Cambridge: Cambridge University Press, 119-146.

Ó Riain, S. (2000): The flexible developmental state: Globalization, information technology, and the "celtic tiger", in: Politics and Society, 28, 2, 157-193.

Offe, C./Ronge, V. (1975): Theses on the theory of the state, in: New German Critique, 6, 137-147.

PAIiIZ. (2004). Yearbook 2003. Warsaw: Polish Information and Foreign Investment Agency.

Porter, M.E. (1990): The competitive advantage of nations. London: Macmillan.

Poulantzas, N. (1976): The crisis of the dictatorships. London: New Left Books.

Przeworski, A./Wallerstein, M. (1988): Structural dependence of the state on capital, in: The American Political Science Review, 82, 1, 11-29.

Shields, S. (2003): The 'charge of the right brigade': Transnational social forces and the neoliberal configuration of Poland's transition, in: New Political Economy, 8, 2, 225244.

Shields, S. (2004): Global restructuring and the Polish state: Transition, transformation, or transnationalization?, in: Review of International Political Economy, 11, 1, 132-154.

Tansey, O. (2007): Process tracing and elite interviewing: A case for non-probability sampling, in: PS: Political Science \& Politics, 40, 4, 765-772.

Trník, M. (2007): The role of investment promotion agencies at attracting foreign direct investment and their impact on economic development in Central Europe (The Czech Republic and Slovakia in comparative perspective). Unpublished MA, Central European University, Budapest.

UNCTAD. (2007): World investment report: Transnational corporations, extractive industries and development. New York and Geneva: United Nations Conference on Trade and Development. 
Vernon, R. (1998): In the hurricane's eye: The troubled prospects of multinational enterprises. Cambridge, MA: Harvard University Press.

Vliegenthart, A./Overbeek, H. (2007): The transnational politics of corporate governance regulation. in: Overbeek, H./Van Apeldoorn, B./Nölke, A. (eds.), The transnational politics of corporate governance regulation, London: Routledge, 177-197.

Wolf, E.R. (1990): Facing power - old insights, new questions, in: American Anthropologist, $92,3,586-596$.

Wright, E.O. (Ed.). (2005): Approaches to class analysis. Cambridge: Cambridge University Press.

Zamkovský, J. (1999): Ako sa loví plachá zver pod Tatrami: Prípad BMW (Hunting shy animals under the Tatras: The case of BMW). Poniky: Friends of the Earth - CEPA. 